\title{
Article \\ Open Field Simulating Nocturnal Warming on Summer Maize Performance in the North China Plain
}

\author{
Junfang Niu ${ }^{1}$, Junxia Feng ${ }^{2}$, Xiying Zhang ${ }^{1, *}$, Suying Chen ${ }^{1}$ and Liwei Shao ${ }^{1}$ \\ 1 Key Laboratory of Agricultural Water Resources, Hebei Laboratory of Agricultural Water-Saving, \\ Center for Agricultural Resources Research, Institute of Genetics and Developmental Biology, Chinese \\ Academy of Sciences, Shijiazhuang 050021, China; niujf@sjziam.ac.cn (J.N.); csy@sjziam.ac.cn (S.C.); \\ liwishao@sjziam.ac.cn (L.S.) \\ 2 School of Chemical Engineering, Shijiazhuang University, Shijiazhuang 050035, China; fengjunxia@126.com \\ * Correspondence: xyzhang@sjziam.ac.cn
}

Citation: Niu, J.; Feng, J.; Zhang, X.; Chen, S.; Shao, L. Open Field

Simulating Nocturnal Warming on Summer Maize Performance in the North China Plain. Agronomy 2021, 11, 992. https://doi.org/10.3390/ agronomy 11050992

Academic Editor: J. Antonio Cortinas Rguez

Received: 31 March 2021

Accepted: 14 May 2021

Published: 17 May 2021

Publisher's Note: MDPI stays neutral with regard to jurisdictional claims in published maps and institutional affiliations.

Copyright: (C) 2021 by the authors Licensee MDPI, Basel, Switzerland. This article is an open access article distributed under the terms and conditions of the Creative Commons Attribution (CC BY) license (https:// creativecommons.org/licenses/by/ $4.0 /)$.

\begin{abstract}
Climate changes show asymmetrical warming, and warming is typically greater at night than during the day. To understand how nocturnal warming (NW) affects the performance of maize (Zea mays L.), an open-field experiment with a free air temperature increase (FATI) facility was conducted for three seasons during 2014 to 2016 at Luancheng eco-agro-experimental station on the North China Plain (NCP). Three nocturnal warming scenarios were set up: the entire growing period (T1, from V4 to maturity), only the vegetative stages (T2, from V4 to a week presilking) and the reproductive stages (T3, from a week presilking to R6). The treatment without NW was the control. Maize lodged seriously in 2015 due to heavy rainfall combined with strong winds, and the experiment failed. The results from 2014 and 2016 were analyzed in this study. During the experimental duration, the average nocturnal temperature was increased by approximately 3.6 and $3.3^{\circ} \mathrm{C}$ at $150 \mathrm{~cm}$ height and 2.0 and $1.7^{\circ} \mathrm{C}$ at the soil surface during the vegetative stages. The corresponding increases were 2.1 and $2.5^{\circ} \mathrm{C}$ and 0.7 and $1.2^{\circ} \mathrm{C}$ at the soil surface during the reproductive stages in 2014 and 2016, respectively, as compared with that of the CK treatment. NW during the whole growth period significantly decreased maize yield for the two seasons. Treatment T2 had a smaller impact on maize yield than T1 and T3. The silking stage was delayed by 2 days in 2014 and 2016 under T1. As a result, presilking duration and VT-R1 interval were prolonged by 1-2 days; and the postsilking duration were shortened by $1-3$ days under T1. The soil moisture in the warmed plots was slightly lower than that in the control plots in the 2014 and during the stages before the earlier grain-filling stages in 2016, but NW decreased soil water content greatly at the later grain-filling stages in 2016, which caused the fast green leaf senescence and exacerbated the negative effects of NW on maize yield. NW for the whole growth duration (T1) significantly decreased seed weight and harvest index. NW increased leaf nighttime respiration rate in both seasons. No significant effects of NW on ear leaf net photosynthesis, leaf area, and specific leaf weight at early grain-filling stage were observed, irrespective of the warming stage and season. The results suggested that reproductive stages were more sensitive to NW compared to vegetative stages under the growing conditions of NCP. The negative effects of NW were worsened in dry seasons. The reduction in maize yield with nocturnal warming was driven by the reduction in the aboveground carbon allocation from shoot to grain during postanthesis stage.
\end{abstract}

Keywords: maize (Zea mays L.); nocturnal warming; phenological phase; photosynthesis and respiration

\section{Introduction}

The global mean air temperature is predicted to increase by approximately $1.0-1.7^{\circ} \mathrm{C}$ by 2050 [1]. Climate changes show asymmetrical warming, and warming is typically greater during the night than during the day, resulting in a narrowing of the diurnal temperature range [2]. Since the temperature is a key factor in regulating crop development and growth, 
future climatic warming will affect the global grain production substantially [3-6]. Crop production is experiencing increases in both the frequency and the intensity of nocturnal warming (NW). NW threatens the sustainability of crop production both currently and in the future. Many studies have indicated that decreased crop yields generally occur as a result of NW. A one-centigrade degree increase in the nighttime temperature can produce a drastic decrease in crop production [3]. Therefore, it has become important to assess the effects of NW on crop production.

Numerous efforts have been made to understand warming impacts on crop production. By employing modeling methods and warming experiments, many studies linking crop yields to historical weather data suggest that impacts from climatic warming on phenological phases and crop yields could vary both spatially and temporally. The results of warming are dependent on the geographical area, crop variety, warming stages, temperature increase intensity, etc. [3,7-15]. High night temperatures are known to decrease yields in several crops such as rice (Oryza sativa L.) [3,14], wheat (Triticum aestivum L.) [16], and corn (Zea Mays L.) [17]. Recent modeling results have shown that global warming may reduce the maize production by $22.8 \%$ for a $5{ }^{\circ} \mathrm{C}$ increase and $13.2 \%$ for a $2{ }^{\circ} \mathrm{C}$ increase in the NCP [11]. In China, the maize yield reduction was estimated around $3.7 \%$ and $11.5 \%$ under global warming by $1.5^{\circ} \mathrm{C}$ and $2.0^{\circ} \mathrm{C}$, respectively [12]. However, there are no consistent results. Climate warming may also lead to positive impacts on the crop yields in some regions. In field warming experiments, an increase of $1.0^{\circ} \mathrm{C}$ in the nighttime temperature enhanced the wheat yield by approximately $10 \%$ on average due to the increase in the seed weight $[13,18]$. Climate warming has benefited maize production in Northeast China at high latitudes [8]. The daily minimum temperature is the dominant factor to maize production in Northeast China, a $1.0^{\circ} \mathrm{C}$ increase in the daily minimum temperature in May or September will lead to an increment of $303 \mathrm{~kg} \mathrm{ha}^{-1}$ or $284 \mathrm{~kg} \mathrm{ha}^{-1}$ in the corn yield, respectively [7]. A winter nocturnal warming (WT) treatment significantly enhanced the wheat grain yield by increasing the grain number and grain weight, while the ST (spring nocturnal warming) treatment had a smaller impact than that of WT treatment [9]. Modeling results in Hebei province indicate that a $1{ }^{\circ} \mathrm{C}$ warming resulted in a $150.2 \mathrm{~kg}$ loss in maize yields per hectare [19]. Most of the simulated results showed that nocturnal warming would be a negative factor in maize production in China, except in Northeast China. However, few field experimental studies have reported whether nocturnal warming decreased maize yields on the North China Plain (NCP).

At present, there is no consensus on the physiological mechanisms of the NW effect on crop production. Previous studies have shown that NW changed the crop phenological phase. Nocturnal warming shortened the length of preanthesis phase by 5-6 days, while it prolonged the length of postanthesis phase by $4-6$ days $[9,13,18]$. The maize development rate was hastened by NW, tassels and silks appeared 1 days earlier and the lag phase of grain filling was shortened by 5 days [17]. It was found that high night temperatures decrease crop production by decreasing photosynthetic functions and sugar and starch contents [20], and by increasing the respiration rate [14]. In addition to decreases in photosynthetic rates, NW can stimulate respiration rates, thereby negatively affecting crop production [13]. An increased rate of leaf respiration rates resulted in higher carbohydrate depletion compared to that of the nonwarmed control [18]. Nocturnal warming also has the possibility of causing male sterility and low pollen viability and hastening crop maturity [14]. However, there are different results regarding NW effects on the duration of grain filling [18]. It was recognized that NW affects the crop nutrient uptake and translocation between vegetative organs and reproductive organs such as carbon and nitrogen [21].

Maize is one of the most important staple crops in the NCP. Thus, understanding the impacts of climatic warming on maize production in the NCP will greatly facilitate the development of strategies and technological innovations needed to ensure future food security. Maize is thermophilic and sensitive to temperature. Previous studies investigating the impact of NW on maize growth used the results of modeling [7] or were executed using 
either passive warming systems or short experimental periods, such as during silking only [17]. Few results on nocturnal warming effects on maize plants have been reported using free air temperature increase systems (FATI). Therefore, field experiments examining the effects of nocturnal warming on the effects of maize production are essential.

The purposes of the present study were to assess whether a moderate increase in the night temperature, while the day-time temperature remained unchanged affects the (i) maize grain production, (ii) phenology, and (iii) net photosynthesis and night respiration rates. The study was conducted in the field at the Luancheng experimental station in the $\mathrm{NCP}$ using a free air temperature increase system. We expect that the results from this study could provide a reference for the future management of maize production to acclimate to climate change for the sustainable development of agriculture and food security in the NCP.

\section{Materials and Methods}

\subsection{Experimental Site}

The open-field warming experiment was conducted at the Luancheng Agro-Ecosystem Experimental Station in the NCP in Hebei Province $\left(37^{\circ} 53^{\prime} \mathrm{N}, 114^{\circ} 41^{\prime} \mathrm{E}\right.$; elevation of $50 \mathrm{~m}$ above sea level) during 2014-2016, which covered three summer maize growing seasons. Winter wheat (Triticum aestivu L.) and summer maize (Zea mays L.) annual double cropping is the predominant system in the NCP. The experimental station is situated in a semi-arid monsoon climate region with $70 \%$ of rainfall occurring during July, August, and September, which constitute the summer maize growing season. At the study site, the annual average temperature was $12.3^{\circ} \mathrm{C}$, and the annual average precipitation was $481 \mathrm{~mm}$. Information on precipitation, the daily maximum and minimum air temperature at the Luancheng station during this period is provided in Figure 1. The soil at the experimental site is sandy loam. The average field capacity was $36 \%\left(\mathrm{~cm}^{3} \mathrm{~cm}^{-3}\right)$, and the wilting point was $13 \%$ $\left(\mathrm{cm}^{3} \mathrm{~cm}^{-3}\right)$ on average for the top $2 \mathrm{~m}$ soil profile. The soil organic matter content was $17.0 \mathrm{~g} \mathrm{~kg}^{-1}$, the total nitrogen was $1.1 \mathrm{~g} \mathrm{~kg}^{-1}$, the available nitrogen was $20.1 \mathrm{mg} \mathrm{kg}^{-1}$, the available phosphorus (P-Olsen) was $26.1 \mathrm{mg} \mathrm{kg}^{-1}$, and the exchangeable potassium was $84.4 \mathrm{mg} \mathrm{kg}^{-1}$ in the top- $20 \mathrm{~cm}$ soil layer.

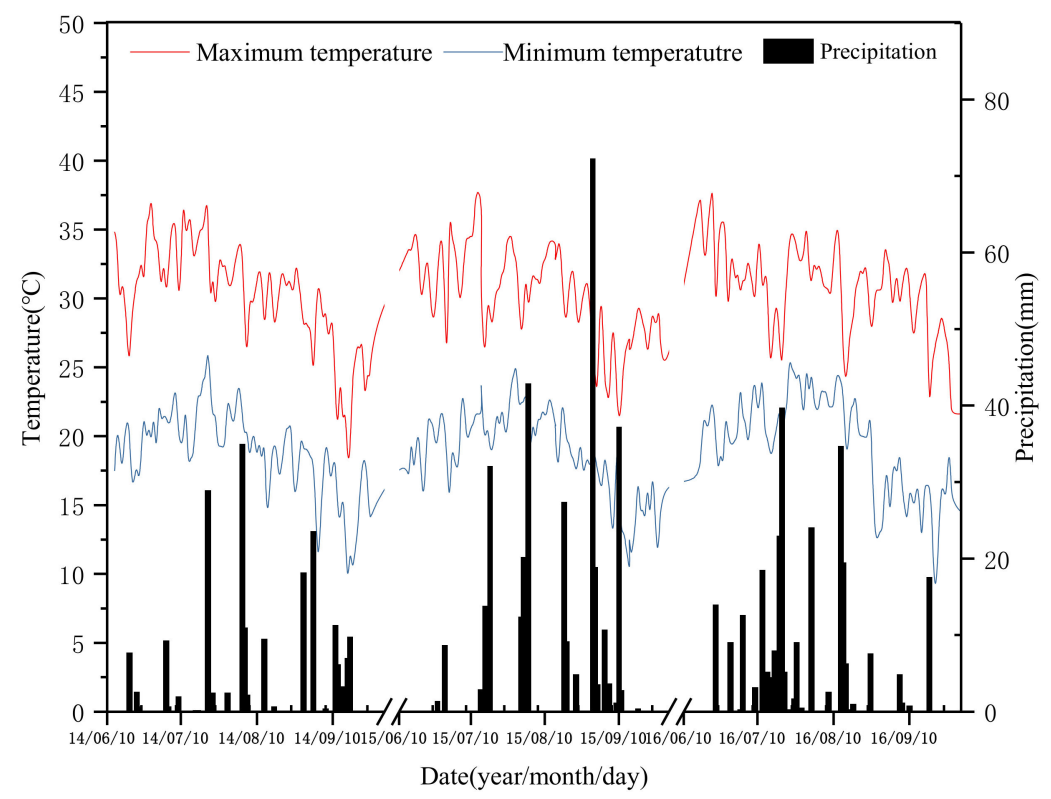

Figure 1. Daily maximum temperature, minimum temperature, and precipitation during maize growing seasons in 2014-2016. 


\subsection{Experimental Design}

A randomized experimental design was used with four temperature treatments, and each treatment was replicated three times (CK: ambient temperature; T1: increased nocturnal temperature during the whole growing period from V 5 to maturity; T2: increased nocturnal temperature only during the vegetative growing period, i.e., from $\mathrm{V} 5$ to about a week before silking; T3: increased nocturnal temperature only during the reproductive period, i.e., from about seven days before silking to maturity). Each plot was $4 \mathrm{~m} \times 5 \mathrm{~m}$ in size, and the distance between two adjacent plots was $8 \mathrm{~m}$ to avoid heating contamination. In 2016, T2 was not conducted according to the results in 2014 and past publications.

A common summer maize cultivar, "Zhengdan958", was manually sown after winter wheat harvesting in early June. At sowing, chemical fertilizers, containing N (urea), P (calcium superphosphate) and $\mathrm{K}$ (potassium chloride), were applied at the rate of $75 \mathrm{~kg} \mathrm{~N} \mathrm{ha}^{-1}$, $65 \mathrm{~kg} \mathrm{P}_{2} \mathrm{O}_{5} \mathrm{ha}^{-1}$, and $75 \mathrm{~kg} \mathrm{~K}_{2} \mathrm{O} \mathrm{ha}^{-1}$. All $\mathrm{P}$ and $\mathrm{K}$ and $30 \%$ of the $\mathrm{N}$ were applied as a basal dressing. In addition, another $175 \mathrm{~kg} \mathrm{~N} \mathrm{ha}^{-1}$ was applied as a topdressing in July with a rainfall event. The planting density was 6 plants $\mathrm{m}^{-2}$, and the sowing and harvesting times are shown in Table 1 . A narrow-wide row spacing of $40-80 \mathrm{~cm}$ was used in this study because it was convenient for sampling and installation of the heaters. After sowing, an irrigation with amount of $60 \mathrm{~mm}$ was immediately applied to ensure seedling establishment. There was no other irrigation during the whole growth duration in 2015 and 2016, except for one additional irrigation added on 19 July 2014 due to less rainfall.

Free air temperature increase systems in this trial was set up as Figure 2. A pair of infrared heaters (each $2 \times 0.02 \mathrm{~m}$ ) was installed above the center of each of the heated plots at a $1 \mathrm{~m}$ distance from each other. Every heater included two heating tubes with a rated power of $1000 \mathrm{~W}$. The effective warming area of each pair of infrared heaters was $2 \times 2 \mathrm{~m}$. All sampling and measurements were performed within this effective $4 \mathrm{~m}^{2}$ area. Initially, the heaters were set at the height of $1.5 \mathrm{~m}$ in the heated plots. To guarantee the warming simulation effect, we used a telescoping mast system to hold the heater throughout the entire growth season. When the height of the maize began reaching the height of the heaters, the heaters were moved upward and thereafter were maintained $0.5 \mathrm{~m}$ above the top of the maize plants. Finally, the heaters were maintained approximately $3 \mathrm{~m}$ above the ground. The treatments without heating were installed with dummy heaters of the same shape and size as the real infrared heaters at the same height to mimic the heater shading effects on the plant canopy. The heating time was from 20:00 to 6:00 the next morning. Heating was applied continuously according to the experimental design, except due to occasional technical problems or during heavy precipitation events and gale weather. Weeds, insects, and diseases were adequately controlled.

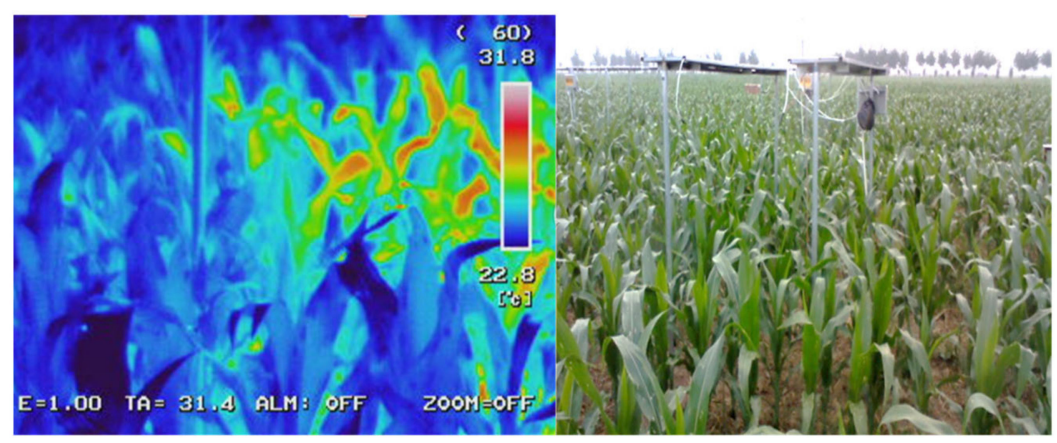

Figure 2. Free air temperature increase systems in the nocturnal warming experiment on maize (photo taken by an infrared camera on 17 July 2014). 
Table 1. Phenology changes as affected by nocturnal warming during 2014 and 2016.

\begin{tabular}{|c|c|c|c|c|c|c|c|c|c|c|}
\hline \multirow{2}{*}{ Year } & \multirow{2}{*}{ Treatment } & \multicolumn{5}{|c|}{ Phenophase Date (day/month) } & \multirow{2}{*}{$\begin{array}{l}\text { VT-R1 Interval } \\
\text { (days) }\end{array}$} & \multirow{2}{*}{$\begin{array}{c}\text { Days before } \\
\text { R1 (days) }\end{array}$} & \multirow{2}{*}{$\begin{array}{c}\text { Days after R1 } \\
\text { (days) }\end{array}$} & \multirow{2}{*}{$\begin{array}{l}\text { Whole Growing } \\
\text { Season (days) }\end{array}$} \\
\hline & & Sowing Date & V6 & VT & R1 & R6 & & & & \\
\hline \multirow{4}{*}{2014} & CK & 13-June & 4-July & 7-August & 8-August & 26-September & 1 & 56 & 48 & 104 \\
\hline & $\mathrm{T} 1$ & 13-June & 4-July & 6-August & 9-August & 25-September & 3 & 57 & 46 & 103 \\
\hline & $\mathrm{T} 2$ & 13-June & 4-July & 6-August & 9-August & 25-September & 3 & 57 & 46 & 103 \\
\hline & $\mathrm{T} 3$ & 13-June & 4-July & 6-August & 8-August & 25-September & 2 & 56 & 47 & 103 \\
\hline \multirow[b]{2}{*}{2016} & CK & 16-June & 7-July & 5-August & 7-August & 27-September & 2 & 51 & 50 & 101 \\
\hline & $\mathrm{T} 1$ & 16-June & 7-July & 5-August & 9-August & 26-September & 4 & 53 & 47 & 100 \\
\hline
\end{tabular}

$\mathrm{CK}, \mathrm{T} 1, \mathrm{~T} 2$, and T3 denote the control, nocturnal warming during the whole growth season, and during the vegetative and the reproductive stages, respectively. 


\subsection{Sampling and Measurement}

\subsubsection{Temperature, Rainfall, and Soil Water Content}

The air temperatures at $0 \mathrm{~cm}$ and $150 \mathrm{~cm}$ above the ground in all treatments were monitored every 20 min from 20:00 to 6:00 each night using Thermo Recorders (L93-4, Loggertech Instrument Co., Ltd., Hangzhou, China). The temperature sensors were set up in the centers of the plots. The soil water contents of the top $40 \mathrm{~cm}$ were monitored every week using the soil auger method. A standard weather station approximately $100 \mathrm{~m}$ away from the experimental site was used to record the atmospheric temperature and rainfall.

\subsubsection{Crop Phenology, Biomass and Yield}

The dates of the main phenological growth stages were recorded, including the 6th leaf stage, tasseling, silking, and physiological maturity. The biomass was measured twice, with one sampling conducted 14 days after silking and another at maturity. Three plants were sampled for each plot, and the total biomass was recorded after oven-drying. For the biomass measurement at maturity, the dry matter of the grains was separated, and the harvest index (HI) was calculated as the fraction of grain dry matter divided by the total aboveground biomass. At maturity, all maize plants in the effective heating areas for each plot, i.e., $4 \mathrm{~m}^{2}$, were harvested to measure the yield and yield components such as the 1000-kernel weight and kernel number per cob.

\subsubsection{Leaf Areas and Specific Ear Leaf Weight}

Leaf areas were measured in situ by the Montgomery method every week when the experiment began and were calculated as the sum of every single-green leaf area. Five plants were selected for each plot, with each leaf measured by the length and maximum width of each blade with a ruler. The single-leaf area was calculated by multiplying the leaf length by the largest width of the leaf and the coefficient of 0.75 . The leaf area index (LAI) was calculated by the average total leaf area per plant and the density. Ear leaves from three plants sampled from each plot and used for biomass measurement 14 days after silking, with the leaves detached from the stems for measuring the specific weight of ear leaf (SLW). The leaf blade was separated along the vein, and then leaf area was measured by a leaf area meter (Licro-3100, LI-COR Inc., Lincoln, NE, USA). The leaves were oven dried for two days at $70{ }^{\circ} \mathrm{C}$ to a constant weight and the dry weight was recorded. The specific leaf weight was calculated by the leaf area divided by the leaf dry weight.

\subsubsection{Leaf Photosynthesis and Respiration Measurement}

The net photosynthesis measurements $\left(\mathrm{Pn}, \mu \mathrm{mol} \mathrm{m}{ }^{-2} \mathrm{~s}^{-1}\right)$ and leaf respiration rate (R) were determined on a sunny day during the daytime between 9 a.m. and 11 a.m. and at nighttime between 10 p.m. and 11 p.m. on the ear leaf, using a Li-6400XT Portable Photosynthesis System (LI-COR Inc., Lincoln, NE, USA), respectively. The chamber was equipped with a red/blue LED light source (LI6400-02B). The light intensity within the chamber was set to follow the natural light intensity from 1000 to $1200 \mu \mathrm{mol} \mathrm{m}{ }^{-2} \mathrm{~s}^{-1}$ for the net photosynthetic rate and $0 \mu \mathrm{mol} \mathrm{m}{ }^{-2} \mathrm{~s}^{-1}$ for the respiration rates. The $\mathrm{CO}_{2}$ concentration was set at $380 \mu \mathrm{mol} \mathrm{mol}^{-1}$. Five ear leaves were randomly selected in each of the warming and control plots. Because the weather was dominated by cloudy and rainy days in mid to late September at the experimental site, leaf photosynthesis measurements were only done twice at the blister and earlier grain-filling stages. Due to the small value of the maize leaf respiration during late growing stages, respiration measurements were only carried out at the blister stage.

\subsection{Statistical Analyses}

Graphs were plotted using Originlab Pro7 (Northampton, MA, USA) and Excel 2016 software. One-way ANOVA was used to test for effects between the control and nocturnal warming treatments. The SAS System for Windows, Release 8.2 (SAS Institute, Cary, NC, USA) was used for all statistical analyses. 


\section{Results}

\subsection{Weather Conditions and Temperature Changes under Nocturnal Warming}

The rainfall amounts in 2014, 2015 and 2016 were $196.4 \mathrm{~mm}, 329.0 \mathrm{~mm}$, and $275.9 \mathrm{~mm}$, respectively, during the summer maize seasons (Figure 1). Compared with the long-term average of $310 \mathrm{~mm}$, the 2014 and 2016 seasons were dry seasons, and the 2015 season was a wet season. Two heavy rainfall events occurred and were accompanied by strong wind on 3 August $(42.3 \mathrm{~mm})$ and 30 August $(72.3 \mathrm{~mm})$, which caused the serious lodging of the maize plants in 2015 season. The examination of the effects of NW on maize could not be continued due to the lodging in this season. Therefore, the heating treatments after lodging were discarded, and the results of the maize performance in 2015 were excluded in this paper.

The daily maximum and minimum air temperatures recorded at the standard weather station are shown in Figure 1 for the three seasons. The mean daily maximum temperatures in 2014,2015 and 2016 seasons were $30.2{ }^{\circ} \mathrm{C}, 30.2^{\circ} \mathrm{C}$, and $30.9^{\circ} \mathrm{C}$, respectively, and the mean daily minimum temperatures were $18.8^{\circ} \mathrm{C}, 18.8^{\circ} \mathrm{C}$, and $19.6^{\circ} \mathrm{C}$, respectively. The average daily temperatures were $24.6^{\circ} \mathrm{C}, 24.7^{\circ} \mathrm{C}$, and $25.5^{\circ} \mathrm{C}$. The diurnal temperature ranges (DTR) were $11.4^{\circ} \mathrm{C}, 11.4^{\circ} \mathrm{C}$, and $11.3^{\circ} \mathrm{C}$, respectively, for the three seasons. The results indicated that the three seasons had similar thermal conditions for the summer maize, with the 2016 season being slightly warmer than the other two seasons.

The night air temperature increments for the warming treatments are shown in Figure 3 . At $150 \mathrm{~cm}$ height above the ground, the nocturnal temperature was increased by 3.6 and $3.3^{\circ} \mathrm{C}$ during the vegetative stage and by 2.1 and $2.5^{\circ} \mathrm{C}$ during the reproductive stage in 2014 and 2016, respectively. The corresponding increase at the ground level was 2.0 and $1.7^{\circ} \mathrm{C}$ during the vegetative stage and $0.7{ }^{\circ} \mathrm{C}$ and $1.2^{\circ} \mathrm{C}$ during the reproductive stage in 2014 and 2016, respectively. In general, the increments during the vegetative stage were higher than those during the reproductive stage because the height of heaters was lower for the former than for the latter. The average temperature increment at $150 \mathrm{~cm}$ and the ground level during the two seasons were $2.7^{\circ} \mathrm{C}$ and $2.8^{\circ} \mathrm{C}$ and $1.2{ }^{\circ} \mathrm{C}$ and $1.4{ }^{\circ} \mathrm{C}$, respectively.

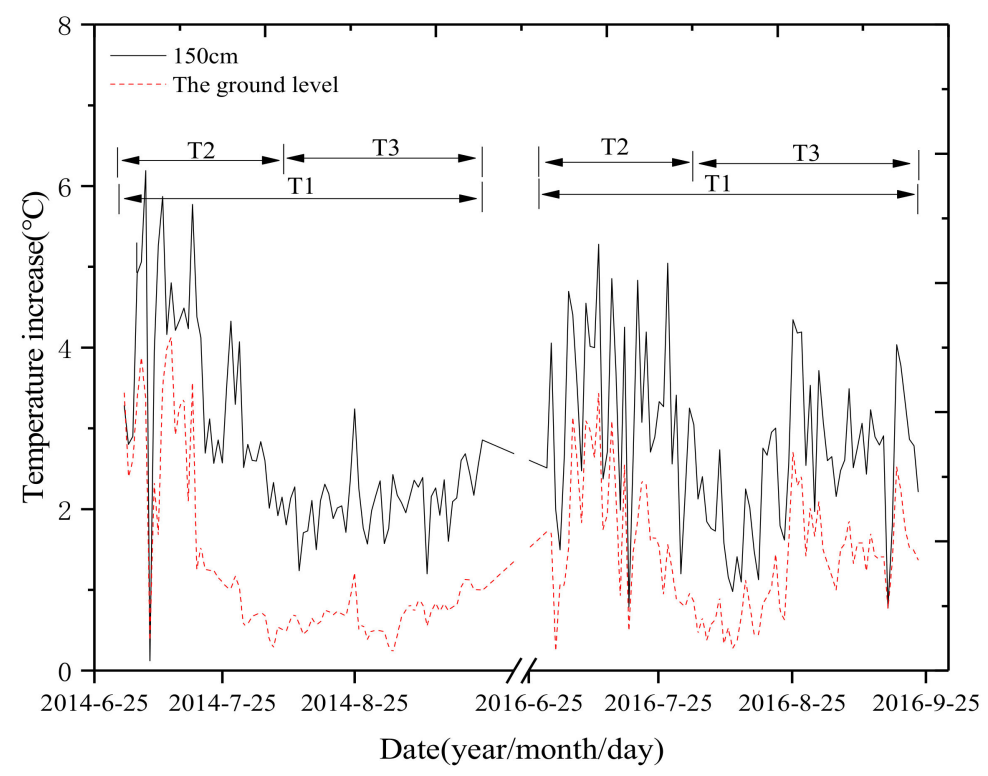

Figure 3. The average night time temperature increase under the nocturnal warming as compared with the control at $150 \mathrm{~cm}$ above-ground and at the ground level during the 2014 and 2016 maize growth season. T2 and T3 denote nocturnal warming during vegetative stages (from V4 to a week presilking) and the reproductive stages (from a week presilking to R6), respectively; and T1 denotes nocturnal warming at the whole growth duration between V4 to R6. 


\subsection{Nocturnal Warming Effects on the Soil Water Content}

Due to the shortage of precipitation in the earlier stages in 2014, the nocturnal warming treatments such as T1 and T2 decreased the soil water content in the top- $40 \mathrm{~cm}$ soil layer compared with the control (Figure 4) in early July. One irrigation was applied to all treatments to replenish the soil water. Due to more rainfall falling afterwards, the soil water contents were similar among different treatments in 2014 (Figure 4). Due to the reduced rainfall during the late growing stages of maize in 2016, the soil water contents in T1 and T3 were lower than that of the control by $10.4 \%$ and $10.3 \%$ (Figure 4 ). The reduced soil water content under NW negatively affected the maize production.

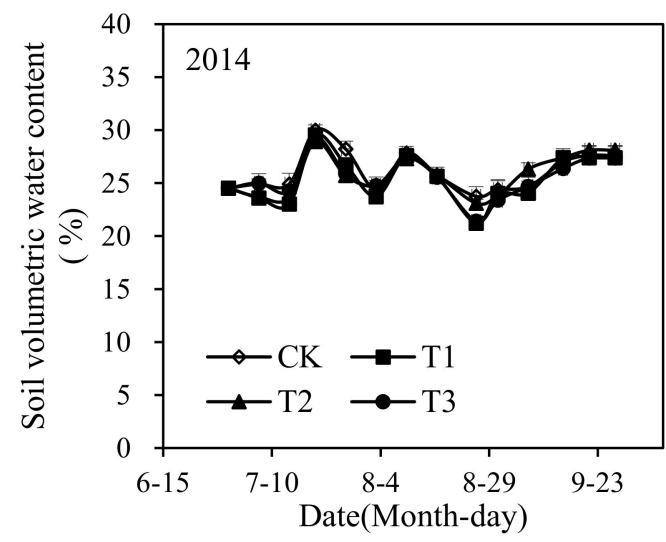

(a)

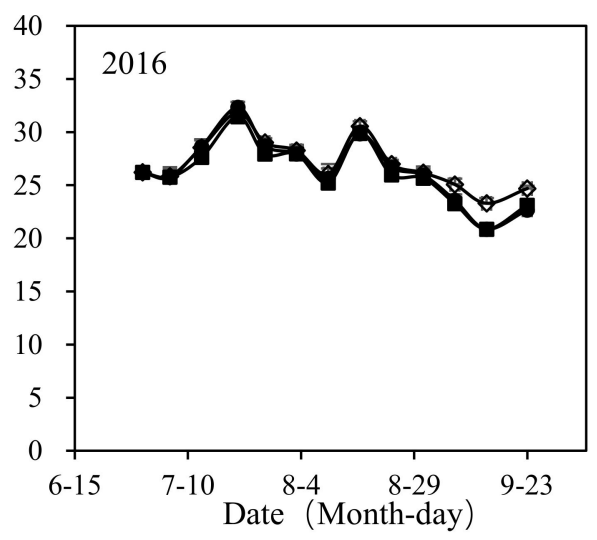

(b)

Figure 4. Mean soil volumetric water content (V/V, 0-40 cm) during the whole growth seasons of maize plants in 2014 (a) and in 2016 (b). CK, T1, T2, and T3 denote the control, nocturnal warming during the whole growth season, and nocturnal warming during the vegetative and reproductive stages, respectively.

\subsection{Crop Development under Nocturnal Warming}

Compared with the control treatment, the phenology of tasseling and maturity in T1, $\mathrm{T} 2$, and $\mathrm{T} 3$ was advanced by one day and the silking stage was delayed by one day in $\mathrm{T} 1$ and T2 in 2014 season (Table 1). Therefore, the anthesis-silking interval (ASI) was increased by two days in T1 and T2 and one day in T3 in 2014 (Table 1). In the 2016 season, only the silking stage was delayed by two days and maturity was advanced by one day in the T1 treatment in 2016 in comparison with the control treatment, resulting in a two-day increase of the ASI value due to NW. The vegetative growth season was extended by one day and two days under T1 in 2014 and 2016, respectively. The reproductive stages after silking were shortened by two days and three days in T1 in 2014 and 2016. In general, the growth duration of maize plants tended to be shortened slightly in 2014 and 2016 by nocturnal warming during the whole growth season (Table 1).

\subsection{Leaf Area Index, Ear Leaf Area, Specific Leaf Weight, and Photosynthesis and Respiration Rates}

Treatments (T1 and T2) under NW had the same LAI during the vegetative stages in 2014 and 2016 seasons (Figure 5), but the LAI was slightly reduced during the stages after silking in 2014, though the difference was not significant (Figure 5). However, at the late grain-filling stage in 2016, because leaf senescence was faster under nocturnal warming, which was possibly related to the low soil water content, the reduction in the green leaf area in T1 and T3 was significant compared with CK, with the green leaf LAI being 17.7\% and $13.3 \%$ lower at maturity (Figure 5). No significant effect occurred on the ear leaf area or specific leaf weight of the leaves at the ear position during the two growing seasons was observed (Figure 6). 


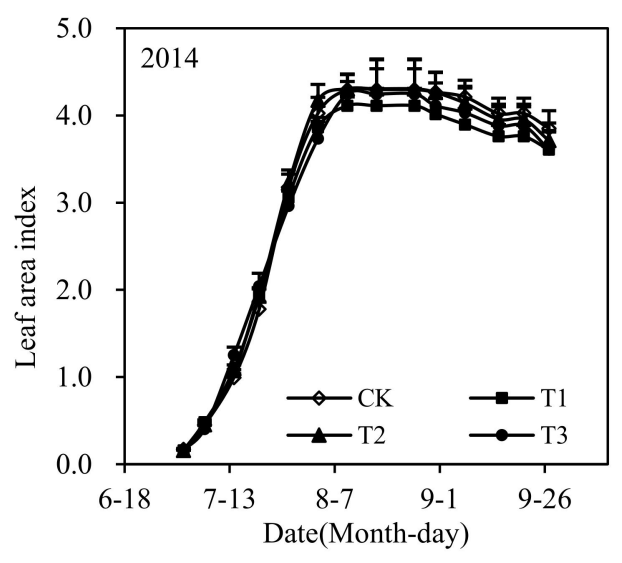

(a)

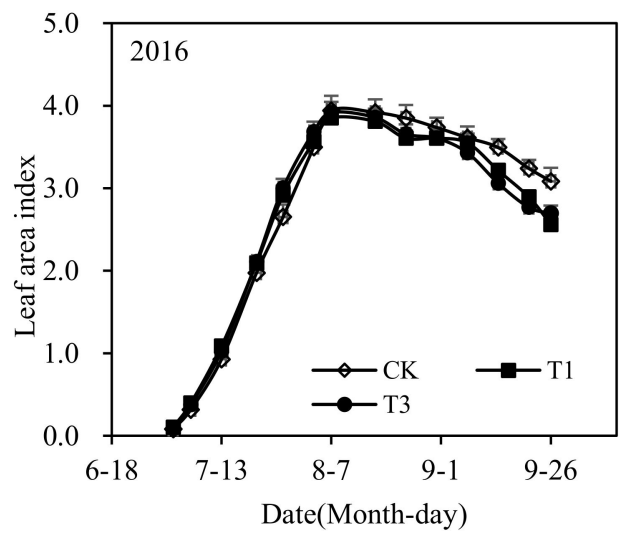

(b)

Figure 5. Leaf area index during the warming growth duration in 2014 (a) and 2016 (b). CK, T1, T2, and T3 denote the control, nocturnal warming during the whole growth season, and nocturnal warming during the vegetative and reproductive stages, respectively.

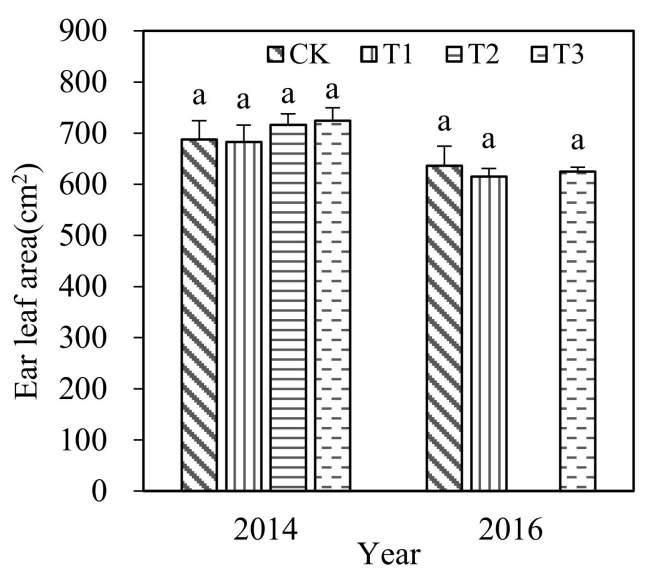

(a)

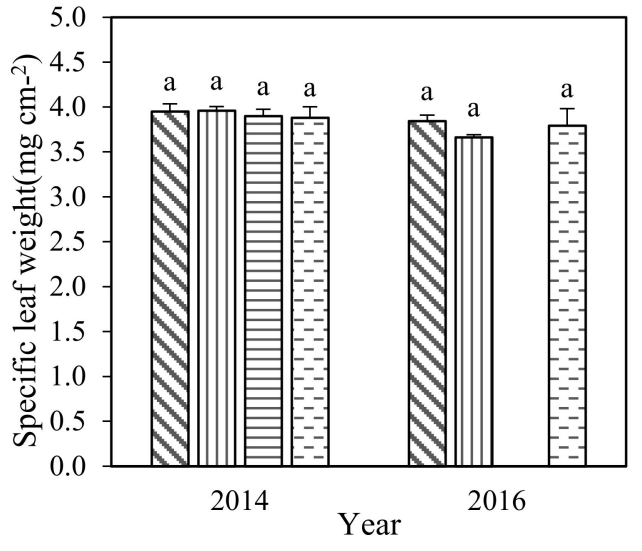

(b)

Figure 6. Leaf areas (a) and specific leaf weight (b) for the ear leaf at blister stage in 2014 and 2016. CK, T1, T2, and T3 denote the control, nocturnal warming during the whole growth season, and nocturnal warming during the vegetative and reproductive stages, respectively. The same letters on the pillar indicate no significant difference among the treatments in the same year $(p<0.05)$.

Nocturnal warming had consistent effects on ear leaf net photosynthesis rate in 2014 and 2016. There were no significant effects of nocturnal warming on the Pn, irrespective the warming stage or growth season (Figure 7). Compared with the Pn, the leaf respiration of ear leaves was relatively smaller. The respiration rate of ear leaves was increased by $40.0 \%$ and $33.3 \%$ under T1 and T3 in 2014. The corresponding increases were $45.6 \%$ and $37.0 \%$ in 2016 season (Figure 8 ). 


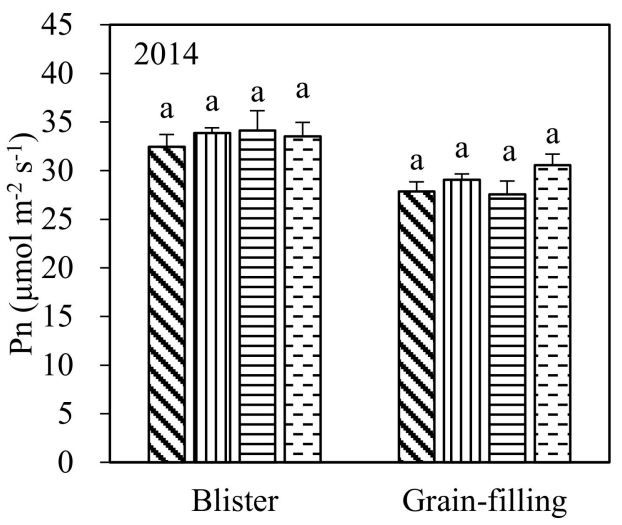

(a)

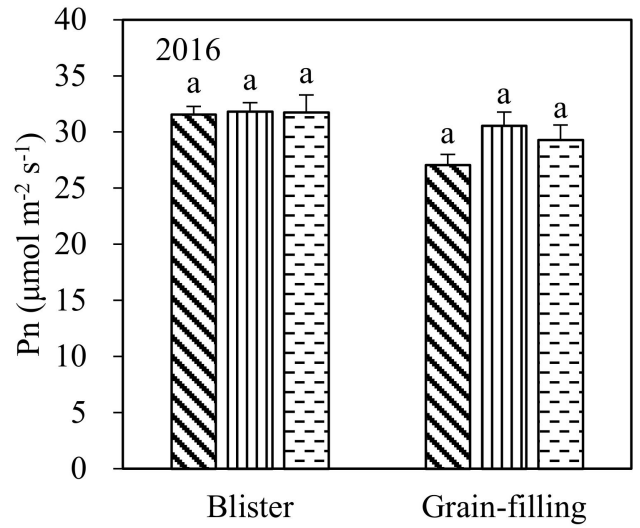

(b)

Figure 7. Ear leaf net photosynthesis rate (Pn) at the blister stage and the early grain-filling stage in 2014 (a) and 2016 (b). CK, T1, T2, and T3 denote the control, nocturnal warming during the whole growth season, and nocturnal warming during the vegetative and reproductive stages, respectively. The same letters on the pillar indicate no significant difference among the treatments in the same year $(p<0.05)$.

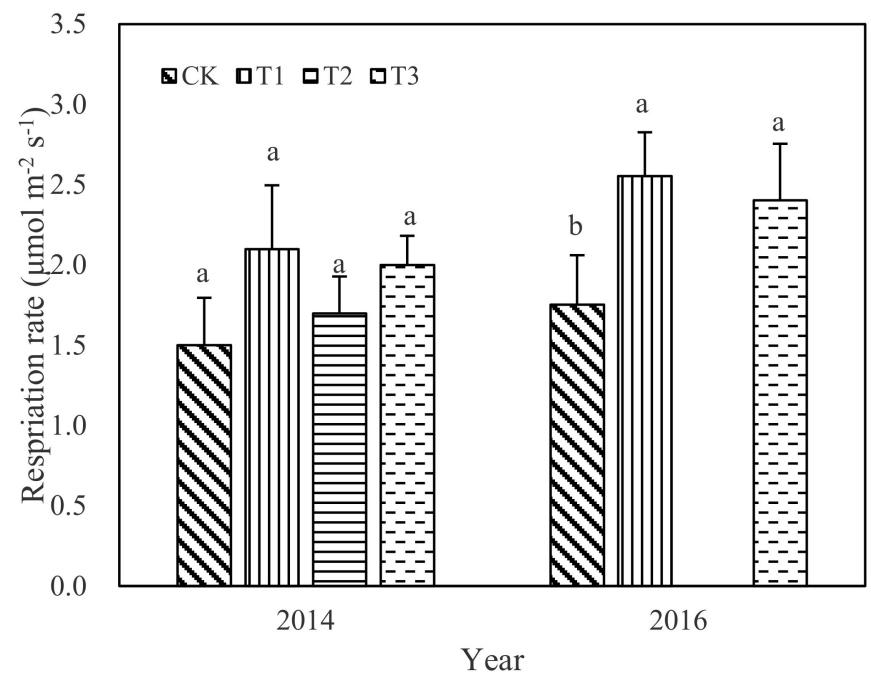

Figure 8. Ear leaf respiration rate (R) at blister stage. CK, T1, T2, and T3 denote the control, nocturnal warming during the whole growth season, and nocturnal warming during the vegetative and reproductive stages, respectively. The same letters on the pillar indicate no significant difference among the treatments in the same year $(p<0.05)$.

\subsection{Grain and Biomass Yield and Grain Yield Components}

Significant differences in maize yields between the nocturnal warming treatment and CK were observed for T1 in 2014 and for both T1 and T3 in 2016 (Table 2). No significant difference in biomass was found among all treatments at the blister stage for the two growing seasons, as there was only a slightly decreasing trend under T1 and T2 compared with CK (Table 2). NW during the whole growth period (T1) decreased the biomass at maturity significantly by $10.2 \%$ and $13.3 \%$ in both growing seasons compared with CK. The T3 treatment slightly reduced the biomass at maturity in 2014 but significantly negatively affected the biomass in 2016 compared with CK. NW during the vegetative stage (T2) did not affect the yield and biomass production in the 2014 season. 
Table 2. Aboveground biomass, grain yield, yield components, and harvest index in 2014 and 2016 seasons.

\begin{tabular}{|c|c|c|c|c|c|c|c|c|}
\hline Year & Treatments & $\begin{array}{l}\text { Aboveground } \\
\text { Biomass at Blister } \\
\text { Stage }\left(\mathrm{kg} \mathrm{ha}^{-1}\right)\end{array}$ & $\begin{array}{c}\text { Aboveground } \\
\text { Biomass at Maturity } \\
\left(\mathrm{Mg} \mathrm{ha}^{-1}\right)\end{array}$ & $\begin{array}{l}\text { Aboveground Biomass } \\
\text { Accumulation between the Blister } \\
\text { and Maturity }\left(\mathrm{kg} \mathrm{ha}^{-1}\right)\end{array}$ & $\begin{array}{c}\text { Yield } \\
\left(\mathrm{kg} \mathrm{ha}^{-1}\right)\end{array}$ & $\begin{array}{l}\text { 1000-Kernel } \\
\text { Weight (g) }\end{array}$ & $\begin{array}{c}\text { Kernel Number } \\
\text { per Cob }\end{array}$ & $\begin{array}{l}\text { Harvest Index } \\
\text { (HI) }\end{array}$ \\
\hline \multirow{3}{*}{2014} & CK & $8341.4 a$ & $15.50 \mathrm{a}$ & 7163.1a & $8213.0 \mathrm{a}$ & $268.8 a$ & $482.1 \mathrm{a}$ & $0.56 a$ \\
\hline & $\mathrm{T} 2$ & $8151.6 a$ & $15.23 a$ & 7077.5a & $8129.0 \mathrm{a}$ & $266.4 a$ & $463.8 \mathrm{a}$ & $0.54 \mathrm{a}$ \\
\hline & $\mathrm{T} 3$ & $8440.2 \mathrm{a}$ & $14.58 \mathrm{ab}$ & $6142.8 b$ & 7932.7ab & $267.9 a$ & $501.5 a$ & $0.53 a b$ \\
\hline \multirow{3}{*}{2016} & CK & $6713.2 a$ & $14.16 \mathrm{a}$ & $7444.2 \mathrm{a}$ & $7784.0 \mathrm{a}$ & $331.7 \mathrm{a}$ & $446.8 \mathrm{a}$ & $0.54 a$ \\
\hline & $\mathrm{T} 1$ & $6312.6 a$ & $12.28 \mathrm{~b}$ & $5964.4 \mathrm{~b}$ & $6671.7 \mathrm{~b}$ & $317.7 \mathrm{~b}$ & $456.5 a$ & $0.51 \mathrm{~b}$ \\
\hline & T3 & $6634.5 \mathrm{a}$ & $12.89 \mathrm{ab}$ & $6257.7 \mathrm{~b}$ & $6773.1 \mathrm{~b}$ & $313.0 \mathrm{~b}$ & $458.9 \mathrm{a}$ & $0.51 \mathrm{~b}$ \\
\hline
\end{tabular}

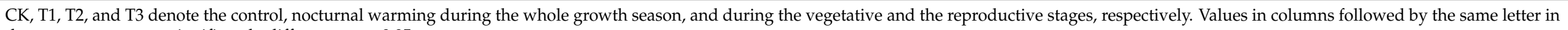
the same year are not significantly different at $p<0.05$ 
NW during the whole growing season (T1) significantly decreased the seed weight in both growing seasons. The harvest index (HI) was reduced greatly in the T1 treatment in 2014 and in the T1 and T3 treatments in 2016. No significant effects on the seed number per ear were found among all treatments in either season. Nocturnal warming during the reproductive stage (T3) slightly reduced the maize yield and harvest index in 2014 but caused significant yield reduction in 2016 (Table 2). There were no apparent effects on the harvest index and other yield components under T2 in 2014. The results indicated that the responses of the maize yield and production under NW were related to the developmental stages by nocturnal warming and climatic conditions changes in different growth seasons.

\section{Discussion}

\subsection{Phenological Effects of NW}

Nocturnal warming changed the crop phenological phase, which was related to the reductions in the crop yields in previous research $[9,13,17,18]$. The period of development centered around flowering, during which the kernel number is defined, has been referred to as the "yield critical period" [22]. Warmer temperatures accelerate the development rate, resulting in shorter vegetative and reproductive phases [23]. In the present study, under NW conditions, the tasseling stage was one day earlier in 2014 in the T1 and T2 treatments. Female flower development was also delayed by two days in 2014 and 2016 under T1 (Table 1). Due to the delayed effects of NW on female flowers relative to those on male flowers, ASI increased by two days (Table 1). Tasseling and silking desynchronization would impede grain setting and lead to kernel abortion and the losses in maize yield. Nocturnal warming caused male sterility, low pollen viability and hastening crop maturity [14]. However, in the results obtained from this experiment, the kernel number per cob was not significantly affected by NW (Table 2), which suggested that the ASI extension by two days did not impede grain setting or cause kernel abortion. The effective grain filling period was shortened by 2-3 days by NW (Table 1), which induced a decrease in the seed weight, and this might be one of the reasons that caused the yield reduction under NW.

\subsection{Photosynthesis and Respiration}

Crop yield formation is the process of carbohydrate accumulation. Carbon gain is strongly linked to efficient photosynthesis and adequate respiration. However, the sensitivities to temperature of photosynthesis and respiration are different. Temperature changes break the balance between photosynthesis and respiration [24,25]. NW had positive [26,27], negative effects [28], and no effect [28] on the photosynthetic rates. The results from this experiment showed that nocturnal warming did not affect the Pn at the blister stage or the early grain-filling stage during both seasons (Figure 7). It is wellrecognized that high night temperatures can stimulate respiration rates at nighttime [18]. In the present experiment, nocturnal warming at the reproductive stages including the $\mathrm{T} 1$ and T3 treatments increased the respiration rate (R) in both seasons, especially in 2016, when significant differences were observed for treatments under NW compared to $\mathrm{CK}$ (Figure 8). Generally, a higher leaf $\mathrm{R}$ rate would result in higher carbohydrate depletion, thereby negatively affecting the yield. However, the stimulation of nighttime respiration and carbohydrate depletion could be compensated for by nocturnal warmingled promotion of daytime photosynthesis and carbohydrate assimilation, which resulted in yield improvement $[18,26]$. Furthermore, plant leaves optimize their carbon assimilation capacity by adjusting the leaf thickness and develop the ability to acquire, transport and utilize resources when their environments change [29,30]. However, we did not find a significant difference in the specific leaf weight of ear leaves in either growing season (Figure 6).

Some researchers have shown that moderate warming at nighttime enlarged the flag leaf area and the postanthesis green leaf areas significantly, which improved the carbon gain and benefitted the yield increase [18]. In the present experiment, nocturnal warming had 
small effects on the leaf area index during the whole growth period in 2014 and 2016, except at the late grain-filling stage in 2016 (Figure 5). Nocturnal warming led to leaf senescence, and the green LAI values at maturity for T1 and T3 were $17.7 \%$ and $13.3 \%$ lower than that of the CK, respectively (Figure 5), which might have been the major reason behind the yield reduction under NW. In both seasons, the ear leaf areas showed no significant effects due to NW (Figure 6). Evapotranspiration was affected by the atmospheric temperatures. The increased temperatures under NW would increase the crop water use. In dry periods when rainfall or irrigation cannot meet the water requirements of crops, the reduced soil water content under NW might negatively affect crop production, such as in the case in 2016. The lower soil water content under NW at late grain-filling stage in 2016 under NW caused rapid leaf senescence, which resulted in the reduction of carbohydrate accumulation and finally caused the reduction in the seed weight (Table 2).

\subsection{Biomass Production and Harvest Index}

The total biomass production and HI determine the final grain yield [31,32]. The results from this study indicated that there was no significant difference among all treatments in the biomass production at the blister stage in both growing seasons. The NW during the vegetative growth stage did not affect the biomass production. However, the aboveground biomass accumulation from blistering to maturity was significantly reduced under T1 and T3 compared with CK (Table 2). Effective grain filling is highly dependent upon the temperature and assimilate availability [33]. NW was found to affect the carbon translocation from vegetative organs to reproductive organs [21]. The seed weight was reduced significantly under T1 in 2014 and under T1 and T3 in 2016 (Table 2). The reduction in the seed weight might be related not only to the reduction in biomass accumulation but also to the reduced carbon allocation to seeds. A reduction of the harvest index (HI) due to NW under the T1 and T3 treatments in 2014 was observed (Table 2). The kernel number per cob did not change much among the treatments (Table 2). Therefore, the differences in the kernel weight among the treatments provided the major contribution to the variations in the grain yield. This is consistent with the result of Zhou et al. [34]. Increased night temperatures affect kernel setting in maize mainly by reducing photoassimilation translocation from shoots to grains during the critical phenological phase for kernel weight determination. The reduction in photo-assimilates was related to the reduction in the green leaf area under NW.

\subsection{Effects of NW during Different Stages on Maize Production}

In the present experiment, NW lasting the whole growth duration or during the reproductive stage significantly reduced the maize yields in 2014 and 2016 (Table 2). These results were consistent with those reported by Cantarero et al. [17]. In China, previous studies have shown that maize yield reductions of $3.7 \%$ and $11.5 \%$ corresponded to $1.5^{\circ} \mathrm{C}$ and $2.0^{\circ} \mathrm{C}$ increases under global warming, respectively [12]. In the NCP, it was reported that $1{ }^{\circ} \mathrm{C}$ warming resulted in a $150.2 \mathrm{~kg} \mathrm{ha}^{-1}$ loss in the maize yield [15]. The long-term meteorological data (1963-2016) during the maize growing season at the experimental station showed that the daily minimum temperature (Tmin) during the maize growing season was significantly increased and that no significant change occurred to the daily maximum temperature (Tmax) [35]. Therefore, the diurnal temperature range (DTR $=$ Tmax-Tmin) decreased significantly. These results indicate that the actual warming effects on the maize yields were mainly caused by NW. Other simulation results showed that the DTR during the grain filling stage had positive effects on the maize yield [36]. In this paper, NW increased Tmin and the DTR was decreased, which caused maize yield reduction (Table 2). However, there are also some results showing no effects from climate warming on maize yields in the NCP [27]. These diversified results are mostly from crop modeling, and the crop models might not be able to precisely simulate the responses of crops to different changes in the nighttime and daytime temperatures. 
The nocturnal warming effects on the maize yield were also related to the warming stages. In the present paper, NW during the whole growth duration (T1), the vegetative stages (T2), and the reproductive stages (T3) decreased the maize yield by $9.3 \%, 1.0 \%$, and $3.4 \%$ in 2014 (Table 2). In 2016, T1 and T3 decreased the maize yield by 14.3 and $13.0 \%$ (Table 2). There were no significant effects on the maize yield by NW during the vegetative stage (T2) in 2014 (Table 2). The yield losses from T3 were greater than those from T2 in 2014, although the temperature increment at the vegetative stage was higher than that during the reproductive stages (Figure 3). Maize grain yield changes are primarily associated with variations in the number of mature kernels which, in turn, depends on the crop growth at silking. NW by approximately $5{ }^{\circ} \mathrm{C}$ at the silking stage decreased the maize kernel setting when using an open-top chamber [17]. The vegetative stages of maize development are less sensitive to high temperatures compared to the reproductive stages $[37,38]$. Our results were consistent with the previous findings. Silking and anthesis (tasseling) are two of the most temperature-sensitive stages for maize [5]. Heat waves during maize reproductive stages alter reproductive growth but have no lasting effects when they occur during vegetative stages [39]. Furthermore, the aboveground biomass accumulation between the blister stage and maturity accounted for $80-90 \%$ of the total grain-yield production. Therefore, NW during the crop reproductive period exerts negative effects on yield-determining processes and can be a critical detrimental factor affecting maize productivity.

\subsection{NW Effects under Different Soil Water Conditions}

The results from this study also indicated that the warming effects were related to the soil water conditions. Elevated temperatures would amplify the negative effects of a water deficit on crop production $[40,41]$. In this study, except for irrigation on the sowing date and in July in 2014, there was no irrigation during the whole growth duration in both growing seasons. Therefore, the soil moisture status mainly depended on the precipitation. The lower rainfall during the productive stage in 2016 resulted in a low soil moisture status, and the soil moisture under T1 and T3 was approximately 10\% lower than that under CK (Figure 4). Nocturnal warming worsened the water stress situation during a dry season and resulted in a larger reduction in crop production. A similar result was found for wheat in the NCP [42]. Warming decreased the wheat yield significantly in the relatively dry year but did not in the relatively wet year. Supplemental irrigation nullified the warming effect completely [42]. Medium water stress did not significantly affect the ecophysiological characteristics during vegetative stages, and water shortages at the flowering and grain filling stages had more adverse effects on the final yield compared to water deficits during the vegetative growth stage [43]. This could explain why T1 in 2014 and T1 and T3 in 2016 had significantly decreased the 1000-grain weight (Table 2), but the weight was not decreased by $\mathrm{T} 2$ treatment (Table 2).

Rainfall during the maize season has shown a declining trend in the NCP [35,44]. It was found that irrigation led to increasing temperatures by enhancing nighttime warming more than daytime cooling during the dry season from 1961 to 2004 in the NCP [45]. The frequency, duration, and severity of climate warming and drought stress events are predicted to increase in the future. The combination of warming and reduced rainfall would increase the negative effects of climate change on maize production in the NCP. Therefore, the severity of nocturnal warming and drought and their interactive effects on crop yield losses should be given more attention in the NCP in the future.

\section{Conclusions}

Nocturnal warming during the reproductive stage significantly decreased maize production, while no such effects were found during the vegetative growing stage. The reduction of the yield under NW was mainly related to the reduction in the seed weight and $\mathrm{HI}$, and these negative effects were more serious under dry soil water conditions. Nocturnal warming increased the leaf nighttime respiration rate but had no significant 
effects on the leaf net photosynthesis rate, leaf area, and specific leaf weight, irrespective of the warming stage and growth seasons. The results from this study suggested that reproductive stages were more sensitive to NW compared to vegetative stages for maize. The reduction in the maize yield under nocturnal warming was driven by the reduced above-ground carbon allocation from shoots to ears during the postanthesis stage. The dynamic characteristics of maize yields are the results of the external environment and internal plant growth regulation, and a trade-off mechanism exists between nocturnal warming and soil water conditions. This should be further studied in the future.

Author Contributions: J.N.: Conceptualization, Investigation, Writing—original draft, Writingreview and editing, Project administration, Funding acquisition. J.F.: Investigation, Writing-review and editing, Statistical analyses. X.Z.: Conceptualization, Writing-review and editing, Project administration, Funding acquisition. S.C.: Investigation. L.S.: Investigation. All authors have read and agreed to the published version of the manuscript.

Funding: This work was financially supported by the National Natural Science Foundation of China (31372131 and 31240014) and International Cooperation Project of MOST (2017YFE0130500).

Institutional Review Board Statement: Not applicable.

Informed Consent Statement: Not applicable.

Data Availability Statement: Not applicable.

Acknowledgments: We are grateful to Xuchuan Nie at Luancheng Agro-Ecosystem Experimental Station for assisting with sampling and measurement in the field.

Conflicts of Interest: The authors declare no conflict of interest.

\section{References}

1. IPCC. Climate Change 2014-Synthesis Report; IPCC: Geneva, Szwitzerland, 2014; p. 10.

2. Easterling, D.R.; Horton, B.; Jones, P.D.; Peterson, T.C.; Karl, T.R.; Parker, D.E.; Salinger, M.J.; Razuvayev, V.; Plummer, N.; Jamason, P.; et al. Maximum and minimum temperature trends for the globe. Science 1997, 277, 364-367. [CrossRef]

3. Peng, S.; Huang, J.; Sheehy, J.E.; Laza, R.C.; Visperas, R.M.; Zhong, X.; Centeno, G.S.; Khush, G.S.; Cassman, K.G. Rice yields decline with higher night temperature from global warming. Proc. Natl. Acad. Sci. USA 2004, 101, 9971-9975. [CrossRef]

4. Wang, X.; Zhao, C.; Müller, C.; Wang, C.; Ciais, P.; Janssens, I.; Peñuelas, J.; Asseng, S.; Li, T.; Elliott, J.; et al. Emergent constraint on crop yield response to warmer temperature from field experiments. Nat. Sustain. 2020. [CrossRef]

5. Sánchez, B.; Rasmussen, A.; Porter, J.R. Temperatures and the growth and development of maize and rice: A review. Glob. Chang. Biol. 2014, 20, 408-417. [CrossRef] [PubMed]

6. Lobell, D.B.; Schlenker, W.; Costa-Roberts, J. Climate trends and global crop production since 1980. Science 2011, 333, 616-620. [CrossRef] [PubMed]

7. Chen, C.; Lei, C.; Deng, A.; Qian, C.; Hoogmoed, W.; Zhang, W. Will higher minimum temperatures increase corn production in Northeast China? An analysis of historical data over 1965-2008. Agricb. For. Meteorol. 2011, 151, 1580-1588. [CrossRef]

8. Meng, Q.; Hou, P.; Lobell, D.B.; Wang, H.; Cui, Z.; Zhang, F.; Chen, X. The benefits of recent warming for maize production in high latitude China. Clim. Chang. 2014, 122, 341-349. [CrossRef]

9. Fan, Y.; Tian, M.; Jing, Q.; Tian, Z.; Han, H.; Jiang, D.; Cao, W.; Dai, T. Winter night warming improves pre-anthesis crop growth and post-anthesis photosynthesis involved in grain yield of winter wheat (Triticum aestivum L.). Field Crops Res. 2015, 178, 100-108. [CrossRef]

10. Yang, H.; Lu, D.; Shen, X.; Cai, X.; Lu, W. Heat stress at different grain filling stages affects fresh waxy maize grain yield and quality. Cereal Chem. 2015, 92, 258-264. [CrossRef]

11. Liu, S.; Mo, X.; Lin, Z.; Xu, Y.; Ji, J.; Wen, G.; Richey, J. Crop yield responses to climate change in the Huang-Huai-Hai plain of China. Agric. Water Manag. 2010, 97, 1195-1209. [CrossRef]

12. Li, K.; Xiong, W.; Pan, J.; Lin, E.; Li, Y.; Han, X. Trend evaluation on changes of maize yield in china under global warming by $1.5^{\circ} \mathrm{C}$ and $2.0^{\circ} \mathrm{C}$. Chin. J. Agrometeorol. 2018, 39, 765-777.

13. Zheng, C.; Zhang, J.; Chen, J.; Chen, C.; Tian, Y.; Deng, A.; Song, Z.; Nawaz, M.M.; van Groenigen, K.J.; Zhang, W. Nighttime warming increases winter-sown wheat yield across major Chinese cropping regions. Field Crops Res. 2017, 214, 202-210. [CrossRef]

14. Mohammed, A.R.; Tarpley, L. Effects of high night temperature and spikelet position on yield-related parameters of rice (Oryza sativa L.) plants. Eur. J. Agron. 2010, 33, 117-123. [CrossRef]

15. Chen, J.; Chen, C.; Tian, Y.; Zhang, X.; Dong, W.; Zhang, B.; Zhang, J.; Zheng, C.; Deng, A.; Song, Z.; et al. Differences in the impacts of nighttime warming on crop growth of rice-based cropping systems under field conditions. Eur. J. Agron. 2017, 82, 80-92. [CrossRef] 
16. Zhang, Y.; Li, R.; Wang, Y. Night-time warming affects $\mathrm{N}$ and P dynamics and productivity of winter wheat plants. Can. J. Plant. Sci. 2013, 93, 397-406. [CrossRef]

17. Cantarero, M.G.; Cirilo, A.G.; Andrade, F.H. Night temperature at silking affects kernel set in maize. Crop. Sci. 1999, 39, 703-710. [CrossRef]

18. Chen, J.; Tian, Y.; Zhang, X.; Zheng, C.; Song, Z.; Deng, A.; Zhang, W. Nighttime warming will increase winter wheat yield through improving plant development and grain growth in north China. J. Plant. Growth Regul. 2014, 33, 397-407. [CrossRef]

19. Chen, Y.; Han, X.; Si, W.; Wu, Z.; Chien, H.; Okamoto, K. An assessment of climate change impacts on maize yields in Hebei province of China. Sci. Total Environ. 2017, 581, 507-517. [CrossRef]

20. Loka, D.A.; Oosterhuis, D.M. Effect of high night temperatures on cotton respiration, ATP levels and carbohydrate content. Environ. Exp. Bot. 2010, 68, 258-263. [CrossRef]

21. Cheng, W.; Sakai, H.; Yagi, K.; Hasegawa, T. Combined effects of elevated $\left[\mathrm{CO}_{2}\right]$ and high night temperature on carbon assimilation, nitrogen absorption, and the allocations of $\mathrm{C}$ and $\mathrm{N}$ by rice (Oryza sativa L.). Agric. For. Meteorol. 2010, 150, 1174-1181. [CrossRef]

22. Borrás, L.; Westgate, M.E.; Astini, J.P.; Echarte, L. Coupling time to silking with plant growth rate in maize. Field Crops Res. 2007, 102, 73-85. [CrossRef]

23. Lizaso, J.I.; Ruiz-Ramos, M.; Rodríguez, L.; Gabaldon-Leal, C.; Oliveira, J.A.; Lorite, I.J.; Sánchez, D.; García, E.; Rodríguez, A. Impact of high temperatures in maize: Phenology and yield components. Field Crops Res. 2018, 216, 129-140. [CrossRef]

24. Dewar, R.C.; Medlyn, B.E.; McMurtrie, R.E. Acclimation of the respiration/photosynthesis ratio to temperature: Insights from a model. Glob. Chang. Biol 1999, 5, 615-622. [CrossRef]

25. Loveys, B.R.; Atkinson, L.J.; Sherlock, D.J.; Roberts, R.L.; Fitter, A.H.; Atkin, O.K. Thermal acclimation of leaf and root respiration: An investigation comparing inherently fast- and slow-growing plant species. Glob. Chang. Biol. 2003, 9, 895-910. [CrossRef]

26. Turnbull, M.H.; Murthy, R.; Griffin, K.L. The relative impacts of daytime and night-time warming on photosynthetic capacity in Popul. deltoides. Plant. Cell Environ. 2002, 25, 1729-1737. [CrossRef]

27. Zheng, Y.; Guo, L.; Hou, R.; Zhou, H.; Hao, L.; Li, F.; Cheng, D.; Peng, Z.; Xu, M. Experimental warming enhances the carbon gain but does not affect the yield of maize (Zea mays L.) in the North China Plain. Flora 2018, 240, 152-163. [CrossRef]

28. Frantz, J.M.; Cometti, N.N.; Bugbee, B. Night temperature has a minimal effect on respiration and growth in rapidly growing plants. Ann. Bot. 2004, 94, 155-166. [CrossRef]

29. Dwyer, J.M.; Hobbs, R.J.; Mayfield, M.M. Specific leaf area responses to environmental gradients through space and time. Ecology 2014, 95, 399-410. [CrossRef]

30. Zhou, H.; Zhou, G.; He, Q.; Zhou, L.; Ji, Y.; Zhou, M. Environmental explanation of maize specific leaf area under varying water stress regimes. Environ. Exp. Bot. 2020, 171, 103932. [CrossRef]

31. Maddonni, G.A.; Otegui, M.E.; Bonhomme, R. Grain yield components in maize-II. Postsilking growth and kernel weight. Field Crops Res. 1998, 56, 257-264. [CrossRef]

32. Otegui, M.E.; Bonhomme, R. Grain yield components in maize-I. Ear growth and kernel set. Field Crops Res. 1998, 56, 247-256. [CrossRef]

33. Cirilo, A.G.; Andrade, F.H. Sowing date and kernel weight in maize. Crop. Sci. 1996, 36, 325-331. [CrossRef]

34. Zhou, B.; Yue, Y.; Sun, X.F.; Wang, X.B.; Wang, Z.M.; Ma, W.; Zhao, M. Maize grain yield and dry matter production responses to variations in weather conditions. Agron. J. 2016, 108, 196-204. [CrossRef]

35. Sun, H.; Liu, C.M.; Wang, Z.H.; Zhang, X.Y.; Dong, B.F. Changing trend of precipitation and its effects on crop productivity in the piedment of Taihang mountain. Chin. J. Eco-Agric. 2007, 15, 18-21.

36. Fang, Q.; Zhang, X.Y.; Chen, S.Y.; Shao, L.W.; Sun, H.Y.; Yan, Z.Z. Selecting traits to reduce seasonal yield variation of summer maize in the North China Plain. Agron. J. 2019, 111, 343-353. [CrossRef]

37. Hatfield, J.L.; Prueger, J.H. Temperature extremes: Effect on plant growth and development. Weather Clim. Extreme. 2015, 10, 4-10. [CrossRef]

38. Shim, D.; Lee, K.-J.; Lee, B.-W. Response of phenology- and yield-related traits of maize to elevated temperature in a temperate region. Crop. J. 2017, 5, 305-316. [CrossRef]

39. Siebers, M.H.; Slattery, R.A.; Yendrek, C.R.; Locke, A.M.; Drag, D.; Ainsworth, E.A.; Bernacchi, C.J.; Ort, D.R. Simulated heat waves during maize reproductive stages alter reproductive growth but have no lasting effect when applied during vegetative stages. Agric. Ecosyst. Environ. 2017, 240, 162-170. [CrossRef]

40. Vanaja, M.; Poldasari, S.; Kumar, G.; Razzaq, A.; Vagheera, P.; Narayana, J.; Yadav, S.; Sarkar, B.; Mandapaka, M. Elevated temperature and moisture deficit stress impact on phenology, physiology and yield responses of hybrid maize. J. Agrometeorol. 2017, 19, 295-300.

41. Song, L.B.; Jin, J.M. Improving CERES-Maize for simulating maize growth and yield under water stress conditions. Eur. J. Agron. 2020, 117, 13. [CrossRef]

42. Li, J.; Dong, W.; Oenema, O.; Chen, T.; Hu, C.; Yuan, H.; Zhao, L. Irrigation reduces the negative effect of global warming on winter wheat yield and greenhouse gas intensity. Sci. Total Environ. 2019, 646, 290-299. [CrossRef] [PubMed]

43. Ge, T.; Sui, F.; Bai, L.; Tong, C.; Sun, N. Effects of water stress on growth, biomass partitioning, and water-use efficiency in summer maize (Zea mays L.) throughout the growth cycle. Acta Physiol. Plant. 2011, 34, 1043-1053. [CrossRef] 
44. Sun, H.Y.; Zhang, X.Y.; Wang, E.L.; Chen, S.Y.; Shao, L.W.; Qin, W.L. Assessing the contribution of weather and management to the annual yield variation of summer maize using APSIM in the North China Plain. Field Crops Res. 2016, 194, 94-102. [CrossRef]

45. Chen, X.; Jeong, S.-J. Irrigation enhances local warming with greater nocturnal warming effects than daytime cooling effects. Environ. Res. Lett. 2018, 13, 024005. [CrossRef] 